\title{
Distribution in Australia and Seed Transmission of Tobacco streak virus in Parthenium hysterophorus
}

Murray Sharman, Department of Primary Industries \& Fisheries (DPI\&F), Plant Pathology Building, 80 Meiers Road, Indooroopilly, Queensland, Australia, and School of Integrative Biology, University of Queensland, St. Lucia Campus, Queensland, Australia; and Denis M. Persley and John E. Thomas, DPI\&F, Indooroopilly, Queensland, Australia

\begin{abstract}
Sharman, M., Persley, D. M., and Thomas, J. E. 2009. Distribution in Australia and seed transmission of Tobacco streak virus in Parthenium hysterophorus. Plant Dis. 93:708-712.

Tobacco streak virus (TSV) was found to commonly occur in Parthenium hysterophorus, as symptomless infections, in central Queensland, Australia across a large area infested with this weed. Several isolates of TSV collected across the geographic range of P. hysterophorus were found to share identical coat protein sequence with each other and with TSV from crop plants in the same area. Seed transmission of TSV in P. hysterophorus was found to occur at rates of 6.8 to $48 \%$. There was almost no change in the rate of TSV seed transmission when $P$. hysterophorus seed was stored for up to $24 \frac{1}{2}$ months. Implications of this relationship between TSV and $P$. hysterophorus for the development of virus disease epidemics in surrounding crops are discussed.
\end{abstract}

Tobacco streak virus (TSV), the type member of the genus Ilarvirus (Family: Bromoviridae), has an extensive host range (7). While the transmission of TSV commonly occurs via thrips and infected pollen $(21,30,33)$, seed transmission has also been demonstrated in a range of plant species $(18,32,34)$. Seed transmission of plant viruses can form a critical link between generations of host plants that may be temporally separated by adverse conditions, such as winter or drought. It can also enable long-distance dispersal of a virus to new locations (23).

In Australia, TSV was first reported in 1971 and has subsequently been reported from tobacco, strawberry, dahlia, and various weed species, mostly from southeastern Queensland (13-15,37). TSV has recently been reported from several field crops in central Queensland (36), causing a yield loss of approximately $20 \%$ across the sunflower industry in central Queensland since 2004 with localized yield losses of greater than $40 \%$ observed in many crops. TSV also caused significant losses in mung bean crops throughout central Queensland in early 2007, with up to $70 \%$ yield reductions in severely affected crops. Losses have been both direct, from crop damage caused by the virus, and indirect from reduced grower confidence in sun-

Corresponding author: M. Sharman

E-mail: murray.sharman@dpi.qld.gov.au

Accepted for publication 22 February 2009.

doi:10.1094/PDIS-93-7-0708

(C) 2009 The American Phytopathological Society flower (unpublished). A similar disease caused by TSV, in a range of crops, has recently been reported from India $(5,6,29)$. A number of alternative weed hosts have been identified in India, including the symptomless host Parthenium hysterophorus (hereafter referred to as parthenium), which was considered to be the principle source of TSV for the development of

Parthenium is an invasive and prolific weed. Believed to have originated from the area of the Gulf of Mexico or central South America, it has been spread extensively during the twentieth century by human activities to many tropical and subtropical regions of the world such as India, Pakistan, Ethiopia, Brazil, Argentina, and Taiwan $(9,28,35,41)$. In Australia, parthenium occurs over an extensive region of central Queensland and in isolated pockets in southeast Queensland. Parthenium has also been recorded in small sporadic outbreaks in northern New South Wales (25). Parthenium seed has been shown to account for greater than $50 \%$ of seed banks at some locations in Queensland (27), and buried seed has a germinable half life of 4 to 6 years $(26,39)$.

Given the recent occurrence of serious crop diseases in central Queensland caused by TSV (36) and the extensive distribution of parthenium, this paper aimed to investigate the possible prevalence and diversity of TSV in parthenium populations across its distribution and the possibility of seed transmission.

\section{MATERIALS AND METHODS}

Field surveys of parthenium populations for TSV infection. Parthenium disease epidemics in nearby crops (30). plants were sampled from 31 sites across its range of distribution in Australia (Fig. 1, Table 1). Sites with a historical record of parthenium were surveyed in northern New South Wales, but parthenium plants were not found. Leaf material from between 4 and 100 plants were sampled from each location, stored at 5 to $10^{\circ} \mathrm{C}$, and indexed for TSV within a few days by enzyme-linked immunosorbent assay (ELISA), essentially as per the manufacturer's instructions (AGDIA ELISA reagent set, Cat. No. SRA25500/0500). Plants were sometimes bulked in groups of up to 5 plants per extract. Coating antibodies and conjugate were used at 1:500, and conjugate was cross absorbed with a mix of healthy Helianthus annuus and Nicotiana tabacum cv. Xanthi n.c. in PBS-T. Leaf tissue was extracted at $0.1 \mathrm{~g}$ per $1 \mathrm{ml}$ of PBS-T including 2\% polyvinylpyrrolidone, with reaction volumes of $50 \mu \mathrm{l}$ in duplicate. Absorbance values $\left(A_{410 \mathrm{~nm}}\right)$ were measured using a Dynatech MR 7000 ELISA plate reader, and values of greater than 3 times the mean of the healthy controls were considered positive.

Test of virus distribution within parthenium plants. Five mature parthenium plants naturally infected with TSV were collected from site 23 northeast of Emerald (Table 1), and plant tissue was tested by ELISA from five different locations on each plant. These included young leaf shoots from two locations: close to the top of the plant and also from a lower branch; flower heads; fully expanded old leaf; and the lower main stem.

Seed transmission tests. Parthenium seeds were collected from four mature plants (seed batches A to D) from site 10 north of Clermont and one plant (batch E) from site 23 northeast of Emerald (Fig. 1). At both locations, seeds were collected from individual plants that were shown to be positive for TSV by ELISA. Another collection of seeds (batch F) from site 10 was bulked from several plants whose virus infection status was unknown but which were growing adjacent to a sunflower crop with approximately 50\% incidence of TSV-like symptoms. Seed was dried to ambient humidity and stored at room temperature until being grown out in the glasshouse. Individual seedlings were indexed for TSV by ELISA at 3 to 5 weeks postplanting, when they were between 10 
and $30 \mathrm{~cm}$ tall, with no floral structures present to avoid the possibility of plant-toplant contamination from infective pollen. Further controls included growing test seedlings in close proximity to the susceptible hosts mung bean (Vigna radiata cv. Emerald), French bean (Phaseolus vulgaris cv. Bountiful), and tobacco (Nicotiana tabacum cv. Xanthi n.c.), which acted as bait plants to detect any thrips transmission. Glasshouses were routinely sprayed with insecticides, and no thrips were detected. Where seed transmission of TSV was detected by ELISA, infection was confirmed from a selection of positive seedlings by mechanical inoculation onto the susceptible indicator hosts mung bean, tobacco, and French bean. A further five ELISA positive and six negative seedlings were assayed by TSV-specific polymerase chain reaction (PCR) as described below.

Test of longevity of TSV in parthenium seed. Individual seedlings were tested from all six batches of seeds (batches A to $\mathrm{F}$ above) at between $2 \frac{1}{2}$ and $3 \frac{1}{2}$ months postcollection; seedlings from four of the batches (B, C, D, and F above) were grown out again for a second test at between $91 / 2$ and 19 months postcollection. Batches $\mathrm{C}$ and $\mathrm{F}$ were also grown out and tested for a third time at between 20 and
28 months postcollection (Table 2). Seed was stored in plastic vials at ambient temperature. Change in seed transmission rates was tested using a chi-square contingency table for comparison of three sampling times and with Fisher's exact test for one degree of freedom for two sampling times (38).

PCR, sequencing, and analysis of TSV isolates. Total RNA was extracted from parthenium leaf tissue using a BioSprint 15 workstation (Qiagen, catalog number 9000850) with a BioSprint 15 Plant DNA kit (catalog number 941514) as per the manufacturer's instructions but without the use of RNase A. SuperScript III reverse transcriptase (Invitrogen) was used to prepare cDNA as per the manufacturer's instructions.

Previously published ilarvirus sequences from GenBank (accession NC_003845, X00435, NC_005854, and NC_008706) were used to design a virus sense primer in the movement protein gene of RNA3, TSVmpF1 (5' CTA TTG AGA AGT CGT GCC TCA A $3^{\prime}$ ). This was used with a TSV-specific antisense primer, TSVcpR2 (36; 5' CCA CAT CGC ACA CAA GTA TTA C $3^{\prime}$ ), located $3^{\prime}$ of the coat protein gene, to amplify a 1,155-bp fragment from each of the six isolates. The fragment con- tained the entire coat protein gene of 717 $\mathrm{nt}$ and partial movement protein gene. PCR was done using 10 pmoles of each primer, 1 unit native Taq DNA polymerase (Invitrogen), $1.75 \mathrm{mM} \mathrm{MgCl} 2,200 \mathrm{mM}$ dNTPs, and $2 \mu \mathrm{l}$ of cDNA template in a $25-\mu \mathrm{l}$ reaction volume. Temperature cycling was in a C1000 Thermal Cycler (Bio-Rad) using initial denaturation of $94^{\circ} \mathrm{C}$ for $60 \mathrm{~s}$, then 35 cycles of: $94^{\circ} \mathrm{C}$ for $15 \mathrm{~s}, 57^{\circ} \mathrm{C}$ for $30 \mathrm{~s}$, and $72^{\circ} \mathrm{C}$ for $60 \mathrm{~s}$; followed by a final extension of $72^{\circ} \mathrm{C}$ for $3 \mathrm{~min}$. PCR products were electrophoresed using an E-gel CloneWell 0.8\% SYBR Safe gel (Invitrogen, catalog number G6618-08) on an iBase (Ethrong Biotechnologies Ltd.) as per the manufacturers' instructions and extracted in water. PCR products were directly sequenced with an Applied Biosystems Inc. automated sequencing system. Sequence alignments, dendrograms, and genetic distances were produced using the Mega3 software package (22). Nucleotide identity searches of the GenBank database were done using the Basic Local Alignment Search Tool (BLAST; 3).

\section{RESULTS}

Field surveys. TSV was present in parthenium at 25 of the 31 sites tested (Table 1). Within the major area of infesta-

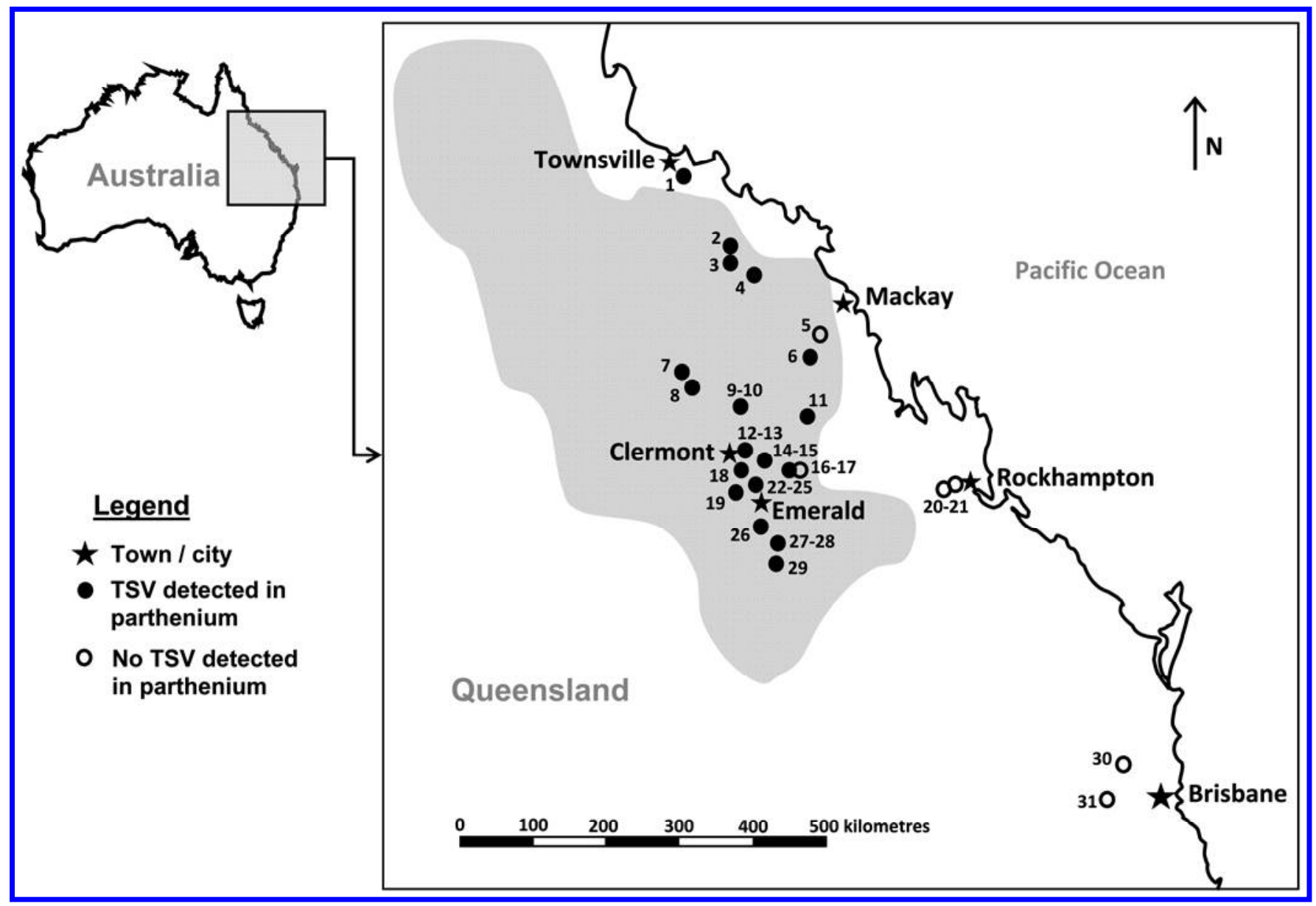

Fig. 1. Distribution of parthenium sampling sites in Queensland, Australia, showing sites where Tobacco streak virus (TSV) was detected (solid dots) and not detected (open circles). Further details of sampling sites are given in Table 1. Shaded area contains regions with heavy infestations of parthenium, adapted from Navie et al. (25). 
tion in central Queensland, TSV was present at 24 out of 26 sites tested (Fig. 1). None of the TSV-infected plants collected displayed virus symptoms. TSV-infected parthenium plants were collected during all seasons of the year and from plants of all ages, from very young seedlings to fully mature plants at least several months old. Six field-infected parthenium plants, previously shown to be positive for TSV by ELISA, were also positive by TSVspecific PCR. These were from locations across the major geographical range of parthenium in Australia. TSV isolate -2012 was collected from site 10, TSV-2077 from site 22, TSV-2084 from site 29, TSV-2087 from site 19, TSV-2103 from site 4, and TSV-2105 from site 1 (Fig. 1, Table 1).

Collections of TSV-positive seedlings listed in Table 1 suggested possible seed transmission. TSV-infected parthenium plants were also collected from grazing land at several sites that were substantial distances from cropping areas.

Distribution of TSV within parthenium plant. There was no significant difference in ELISA absorbance values from the different plant tissue types tested, al- though the flowers had the least amount of variation in values and were consistently high. From the five plants tested, $A_{410} \mathrm{~nm}$ absorbance values ranged from 0.260 to 0.327 for flowers, 0.104 to 0.298 for young leaves, 0.157 to 0.388 for old leaves, and 0.157 to 0.274 for the main stem compared to 0.004 for a healthy parthenium control.

Seed transmission and longevity. Seed transmission of TSV was demonstrated from all six batches of seed tested and ranged from $6.8 \%$ for batch $\mathrm{E}$ to $48 \%$ for batch A (Table 2). None of the infected

Table 1. Sample site details and results of Tobacco streak virus (TSV) testing for Parthenium hysterophorus plants

\begin{tabular}{|c|c|c|c|c|c|c|c|c|}
\hline $\begin{array}{l}\text { Site } \\
\text { number }\end{array}$ & Latitude $^{\mathbf{a}}$ & Longitude & Land use & Age of plants & $\begin{array}{l}\text { Collection } \\
\text { month }\end{array}$ & $\begin{array}{c}\text { Total } \\
\text { individuals }\end{array}$ & $\begin{array}{c}\text { Positive individuals } \\
\text { or bulks }\end{array}$ & $\begin{array}{l}\text { Sample } \\
\text { bulking }^{\mathrm{c}}\end{array}$ \\
\hline 1 & -19.39840 & 146.9484 & Grazing & Mature & October & 22 & $2 / 22$ & $\mathrm{a}$ \\
\hline 2 & -20.46834 & 147.5928 & Grazing & Mature & October & 18 & $2 / 18$ & $\mathrm{a}$ \\
\hline 3 & -20.51579 & 147.5925 & Grazing & Mature & October & 15 & $1 / 15$ & $\mathrm{a}$ \\
\hline 4 & -20.65705 & 147.8613 & Grazing & Mature & October & 12 & $1 / 12$ & $\mathrm{a}$ \\
\hline 5 & -21.52040 & 148.7789 & Forest & Mature & January & 13 & $0 / 5$ & $\mathrm{a}, \mathrm{b}$ \\
\hline 6 & -21.84299 & 148.6273 & Grazing & Mature & January & 24 & $6 / 12$ & $\mathrm{c}$ \\
\hline 7 & -22.03670 & 147.1082 & Grazing & Mature & January & 39 & $9 / 13$ & $\mathrm{~b}$ \\
\hline 8 & -22.20378 & 147.2379 & Cropping & Mature & January & 33 & $10 / 11$ & $\mathrm{~b}$ \\
\hline 9 & -22.38065 & 147.6767 & Cropping & Seedlings & August & 100 & $11 / 20$ & d \\
\hline 10 & -22.40488 & 147.6951 & Cropping & Seedlings & February & 51 & $16 / 51$ & $\mathrm{a}$ \\
\hline 10 & -22.40488 & 147.6951 & Cropping & Mature & April & 4 & $4 / 4$ & $\mathrm{a}$ \\
\hline 11 & -22.51065 & 148.5592 & Cropping & Mature & March & 8 & $1 / 8$ & $\mathrm{a}$ \\
\hline 12 & -22.78142 & 147.7934 & Cropping & Seedlings & February & 40 & $1 / 40$ & $\mathrm{a}$ \\
\hline 13 & -22.79212 & 147.7756 & Cropping & Mature & April & 56 & $25 / 28$ & $\mathrm{c}$ \\
\hline 14 & -22.84174 & 148.0706 & Grazing & Mature & September & 10 & $5 / 5$ & $\mathrm{c}$ \\
\hline 15 & -22.90582 & 148.0772 & Cropping & Mature & September & 11 & $5 / 5$ & $\mathrm{~b}, \mathrm{c}$ \\
\hline 15 & -22.90582 & 148.0772 & Cropping & Seedlings & January & 20 & $0 / 20$ & $\mathrm{a}$ \\
\hline 15 & -22.90582 & 148.0772 & Cropping & Mature & January & 38 & $2 / 13$ & $\mathrm{~b}, \mathrm{c}$ \\
\hline 16 & -23.04613 & 148.3193 & Cropping & Mature & September & 21 & $4 / 10$ & $\mathrm{~b}, \mathrm{c}$ \\
\hline 17 & -23.05149 & 148.4679 & Grazing & Mature & September & 26 & $0 / 13$ & $\mathrm{c}$ \\
\hline 18 & -23.05221 & 147.9269 & Cropping & Mature & September & 9 & $1 / 9$ & $\mathrm{a}$ \\
\hline 19 & -23.34846 & 147.7053 & Forest & Mature & September & 26 & $2 / 13$ & $\mathrm{c}$ \\
\hline 20 & -23.41017 & 150.4997 & Grazing & Mature & April & 12 & $0 / 12$ & $\mathrm{c}$ \\
\hline 21 & -23.44035 & 150.4300 & Grazing & Mature & April & 25 & $0 / 17$ & $\mathrm{a}, \mathrm{c}$ \\
\hline 22 & -23.28802 & 148.0732 & Cropping & Mature & August & 9 & $3 / 3$ & $\mathrm{~b}$ \\
\hline 23 & -23.45401 & 148.3307 & Cropping & Mature & November & 30 & $11 / 20$ & $\mathrm{a}, \mathrm{c}$ \\
\hline 23 & -23.45401 & 148.3307 & Cropping & Mature & February & 6 & $6 / 6$ & $\mathrm{a}$ \\
\hline 24 & -23.47274 & 148.0807 & Cropping & Mature & January & 30 & $6 / 10$ & $\mathrm{~b}$ \\
\hline 25 & -23.48871 & 148.1449 & Cropping & Mature & February & 6 & $6 / 6$ & $\mathrm{a}$ \\
\hline 26 & -23.76367 & 148.1063 & Cropping & Various & August & 42 & $4 / 10$ & $\mathrm{a}, \mathrm{d}$ \\
\hline 27 & -23.98075 & 148.3448 & Cropping & Mature & September & 19 & $6 / 9$ & $a, b, c$ \\
\hline 27 & -23.98075 & 148.3448 & Cropping & Mature & March & 11 & $11 / 11$ & a \\
\hline 28 & -24.04109 & 148.4142 & Cropping & Mature & September & 5 & $2 / 3$ & $\mathrm{a}, \mathrm{c}$ \\
\hline 29 & -24.22601 & 148.3642 & Grazing & Mature & September & 17 & $6 / 8$ & $\mathrm{~b}, \mathrm{c}$ \\
\hline 30 & -26.94705 & 152.5000 & Grazing & Mature & May & 64 & $0 / 32$ & $\mathrm{c}$ \\
\hline 31 & -27.55270 & 152.0969 & Grazing & Mature & May & 38 & $0 / 19$ & $\mathrm{c}$ \\
\hline
\end{tabular}

${ }^{a}$ Latitude and longitude are shown as degrees only using the map datum WGS 84.

${ }^{\mathrm{b}}$ Number of TSV-positive samples and total number of samples tested. A sample may represent one individual plant or a bulk of individual plants.

${ }^{c}$ Samples were either tested as individuals (a), in triples (b), in pairs (c), in bulks of 5 (d), or using combinations of these.

Table 2. Transmission rate of Tobacco streak virus (TSV) in parthenium seed over time ${ }^{\mathrm{a}}$

\begin{tabular}{|c|c|c|c|c|c|c|c|c|}
\hline \multirow[b]{2}{*}{ Seed batch } & \multicolumn{2}{|c|}{ First test } & \multicolumn{3}{|c|}{ Second test } & \multicolumn{3}{|c|}{ Third test } \\
\hline & $\begin{array}{l}\text { Storage time } \\
\text { (months) }\end{array}$ & $\begin{array}{c}\text { Proportion of } \\
\text { seedlings infected }\end{array}$ & $\begin{array}{l}\text { Storage time } \\
\text { (months) }\end{array}$ & $\begin{array}{c}\text { Proportion of } \\
\text { seedlings infected }\end{array}$ & $P$ value $^{\mathrm{b}}$ & $\begin{array}{l}\text { Storage time } \\
\text { (months) }\end{array}$ & $\begin{array}{c}\text { Proportion of } \\
\text { seedlings infected }\end{array}$ & $P$ value $^{c}$ \\
\hline A & $21 / 2$ & $24 / 50$ & $\mathrm{n} / \mathrm{t}^{\mathrm{d}}$ & - & - & $\mathrm{n} / \mathrm{t}$ & - & - \\
\hline B & $21 / 2$ & $11 / 50$ & 11 & $12 / 50$ & 0.818 & $\mathrm{n} / \mathrm{t}$ & - & - \\
\hline $\mathrm{C}$ & $21 / 2$ & $14 / 50$ & 11 & $10 / 32$ & - & 20 & $19 / 50$ & 0.558 \\
\hline $\mathrm{D}$ & $21 / 2$ & $19 / 50$ & $91 / 2$ & $11 / 32$ & 0.728 & $\mathrm{n} / \mathrm{t}$ & - & - \\
\hline $\mathrm{E}$ & $2^{1 / 2}$ & $3 / 44$ & $\mathrm{n} / \mathrm{t}$ & - & - & $\mathrm{n} / \mathrm{t}$ & - & - \\
\hline $\mathrm{F}$ & $31 / 2$ & $16 / 56$ & 19 & $14 / 50$ & - & 28 & $13 / 50$ & 0.954 \\
\hline
\end{tabular}

a $P$ values are shown to compare rates of transmission over time.

${ }^{\mathrm{b}} P$ value for change in proportion of infected plants over time from the first to second test using Fisher's exact estimate

${ }^{\text {c }} P$ value for change in proportion of infected plants over time from the first to third test using standard chi-square analysis.

$\mathrm{d} \mathrm{n} / \mathrm{t}=$ not tested. 
plants displayed any symptoms. ELISA values for infected plants were 4 to 73 times the averages of the healthy controls, with more than $90 \%$ of these being higher than 6 times the healthy average. Systemic symptoms typical of TSV infection were observed for all ELISA-positive test plants that were mechanically inoculated to the indicator hosts French bean, mung bean, and tobacco. All five ELISA-positive test plants also tested by TSV-specific PCR produced typical bands of the expected size, while all six ELISA-negative plants did not produce any bands by PCR. There was no significant change in the rate of seed transmission over a time period of up to $24 \frac{1}{2}$ months for the four batches of seed tested on more than one occasion. None of the susceptible bait plants grown next to the parthenium seedlings displayed any symptoms during any of these tests.

PCR, sequencing, and analysis. The predicted product size of $1,155 \mathrm{bp}$ was amplified from all six TSV isolates by PCR. Sequence data for isolate TSV-2012 has been lodged in the GenBank database, accession number EU871659. After removal of primer sequences, the resulting sequence was $1,084 \mathrm{bp}$ in length. This includes the $3^{\prime}$ terminal $200 \mathrm{nt}$ of the putative movement protein gene, the intergenic region, and the complete 717 -nt putative coat protein gene. The predicted size of the putative coat protein is 238 amino acids for all six isolates.

The nucleotide sequences of the six TSV isolates from parthenium and the recently published Australian sunflower isolate (TSV-1974; GenBank accession EU375481) were $>99.5 \%$ identical, and these seven sequences from Australia had $>98 \%$ identity with a Brazilian TSV isolate reported from soybean (2; AY354406) over a 747-nt overlap. The next closest nucleotide sequence identity by BLAST was approximately $80 \%$ between the parthenium isolates and a TSV isolate from white clover, United States of America (USA; NC_003845) over a 1,069-nt overlap.

\section{DISCUSSION}

At least two accidental introductions of parthenium into Australia have occurred. The first, in 1955, was near Toogoolawah in southeast Queensland, although this infestation has not spread significantly (4). The second, far more invasive introduction occurred in 1958 into central Queensland, north of Clermont, and this introduction is believed to have been from Texas, through the importation of contaminated pasture seed $(10,16,28)$. The major area of parthenium infestation now covers an extensive region of central Queensland. Some isolated infestations occur outside this region, and its presence has been recorded in southern regions of Queensland and into northern NSW (25; Fig. 1).

Parthenium is an opportunistic weed, and given adequate soil moisture it is able to germinate, grow, and shed prolific numbers of seeds (achenes) in less than 2 months, but will survive for much longer if sufficient moisture is maintained $(17,25)$. It can complete its life cycle at a wide range of temperatures (39) and will do so at any time of year in Queensland (16).

This is the first record of TSV seed transmission in P. hysterophorus. Varying rates of TSV seed transmission in other naturally infected hosts have been reported, including 3\% in Melilotus alba (19), 1.4 to $6 \%$ in Phaseolus vulgaris cv. Pinto (40), $3.8 \%$ in P. vulgaris cv. Black Turtle Soup (18), and about 6\% in Raphanus raphanistrum (8). The rates of TSV seed transmission found in naturally infected parthenium in this study are relatively high at between 6.8 and $48 \%$. The wide variation of observed rates of transmission in parthenium may be related to the time of infection of the mother plant, as has been observed with other viruses (12).

It is possible that TSV was accidently introduced into Australia via TSV-infected parthenium seed in the mid-twentieth century from the United States, and it has subsequently been spread with the movement of parthenium throughout central Queensland. If TSV did arrive in Australia in parthenium seed, it is unclear why it has only been noticed in crops within the last 10 years when high densities of parthenium have been present in many parts of central Queensland for at least 30 years. There may have been a slow increase in incidence of TSV in parthenium over time and only recently has TSV reached high enough incidence to move into, and cause noticeable disease levels in, nearby susceptible crops. Interestingly, TSV was not detected at sites $20,21,30$, or 31 , which are isolated infestations separated from, but believed to have originated from, the major area of infestation in central Queensland (C. McGaw, personal communication). This may indicate that these sites became established from a low number of seed from central Queensland which by chance did not contain TSV, or TSV has only recently become widespread in central Queensland parthenium. It is also possible that TSV was accidently introduced into Australia via seed of another host (possibly a crop) recently and has subsequently become established in parthenium. However, the survey results indicated that TSV is randomly distributed throughout the geographical range of parthenium with no obvious association with surrounding land use.

TSV is pollen-borne, and transmission of TSV to healthy plants relies on the virus from infected pollen entering plant cells through the feeding injury caused by thrips (33). Surveys of pollen diversity and abundance from several Indian cities indicate the potential for large quantities of parthenium pollen to become airborne and moved significant distances $(20,24,31)$. Hence, parthenium is an ideal alternative host for generating TSV disease epidemics as it produces large amounts of pollen which is easily dispersed by wind or thrips. The high rates of seed transmission and long-term viability of TSV in parthenium seed demonstrated in this study, along with the ability of parthenium to often dominate seed banks, remain viable for many years $(26,27)$, and produce large amounts of TSV-infected pollen, indicates that parthenium plays a critical role in the life cycle of TSV in central Queensland.

The dry tropical climate of Emerald is typical of central Queensland, with most of its approximately $600 \mathrm{~mm}$ of annual rainfall being received in warm summer months followed by dry, mild winters. Drought periods are not uncommon during which very few alternative host plants of TSV survive and most TSV-susceptible crops are only grown in summer. Seed transmission of TSV in parthenium enables the rapid development of TSV epidemics, even after prolonged adverse conditions such as drought and/or harsh winters, and provides a link between favorable seasons and cropping cycles. It would also enable the long-distance dispersal of TSV into new agricultural regions with the movement of parthenium seed on machinery, livestock, or in harvested goods.

Coat protein sequence from six parthenium isolates indicated that only one strain of TSV is present in parthenium across the area of major infestation, and this strain is the same as that reported to cause the sunflower necrosis disorder in crops from the same region (36). However, coat protein sequence data for TSV isolates from southeast Queensland indicates a significant difference from the isolates from central Queensland (unpublished). Thus, while TSV was first reported from southeast Queensland in the early 1970s (13), it is clear there has been a separate introduction and spread of the central Queensland strain of TSV. It is likely that TSV from Brazil and central Queensland share a common origin because strains from central Queensland and Brazil (GenBank AY354406) are genetically very similar to each other but distinct from all other reported TSV strains, including those reported to cause crop diseases from India (5).

Prasada Rao et al. (30) suggested that parthenium was a widely distributed alternative host of TSV and that it was crucial for the development of virus epidemics in nearby peanut crops in India. While they found no seed transmission of TSV in sunflower, parthenium seed was not tested. Results presented here warrant the investigation of TSV seed transmission in parthenium from other regions of the world where parthenium and TSV are present, such as India. In the state of Parana, Brazil, Ambrosia polystachia, an Asteraceae species, is reportedly an important alterna- 
tive host associated with soybean bud blight disease caused by TSV (1). The status of TSV seed transmission in $A$. polystachia has not been reported. Interestingly, Parthenium hysterophorus also occurs in the state of Parana, Brazil, where it is reported to infest soybean crops (11). While no mention of parthenium has been made in the literature in relation to TSV in Brazil, the results of this study suggest parthenium may also be an important host of TSV in that country, particularly considering the Brazilian and central Queensland strains of TSV are very similar by sequence analysis and may share very similar biological characteristics.

The widespread distribution of TSVinfected parthenium and the propensity for seed transmission in this host indicate it plays an important role in the epidemiology of TSV in central Queensland. However, several other aspects of the epidemiology of TSV in central Queensland may be important and are under further investigation, including the range of other alternative hosts and the thrips vector species responsible for transmission of TSV into crops. Control strategies may include the control of parthenium next to cropping areas, crop location based on likely risk, and the use of tolerant or resistant cultivars and barrier crops, some of which are also being investigated in India (30).

\section{ACKNOWLEDGMENTS}

This work was funded by the Grains Research and Development Corporation, the Cotton Research and Development Corporation, and the Department of Primary Industries and Fisheries, Queensland. We thank Rosemary Kopittke for assistance with statistical analyses, and Steven Matheson, Ian Walker, Clyde McGaw, and central Queensland grain growers for assistance with location of, and access to, sampling sites.

\section{LITERATURE CITED}

1. Almeida, A. M. R., and Corso, I. C. 1991. Effect of sowing time on the incidence of bud blight in soybean (Glycine $\max$ L. Merr.). J. Phytopathol. 132:251-257.

2. Almeida, A. M. R., Sakai, J., Hanada, K., Oliveira, T. G., Belintani, P., Kitajima, E. W., Souto, E. R., de Novaes, T. G., and Nora, P. S. 2005. Biological and molecular characterization of an isolate of Tobacco streak virus obtained from soybean in Brazil. Fitopatol. Bras. 30:366-373.

3. Altschul, S. F., Gish, W., Miller, W., Myers, E. W., and Lipman, D. J. 1990. Basic local alignment search tool. J. Mol. Biol. 215:403410.

4. Auld, B. A., Hosking, J., and McFadyen, R. E. 1983. Analysis of the spread of tiger pear and parthenium weed in Australia. Aust. Weeds 2:56-60.

5. Bhat, A. I., Jain, R. K., Chaudhary, V., Krishna Reddy, M., Ramiah, M., Chattannavar, S. N., and Varma, A. 2002. Sequence conservation in the coat protein gene of Tobacco streak virus isolates causing necrosis in cotton, mungbean, sunflower and sunn-hemp in India. Indian J. Biotechnol. 1:350-356.

6. Bhat, A. I., Jain, R. K., and Ramiah, M. 2002. Detection of Tobacco streak virus from sunflower and other crops by reverse transcription polymerase chain reaction. Indian Phytopathol. 55(2):216-218.

7. Brunt, A. A., Crabtree, K., Dallwitz, M. J., Gibbs, A. J., and Watson, L. 1996. Viruses of Plants. CAB International, Wallingford, UK.

8. Cupertino, F. P., Grogan, R. G., Peterson, L. J., and Kimble, K. A. 1984. Tobacco streak virus infection of tomato and some natural weed hosts in California. Plant Dis. 68:331-333.

9. Evans, H. C. 1997. Parthenium hysterophorus: A review of its weed status and the possibilities for biological control. Biocontrol News Inform. 18(3):89N-98N.

10. Everist, S. L. 1976. Parthenium weed. Queensl. Agric. J. 102:2.

11. Gazziero, D. L. P., Brighenti, A. M., and Voll, E. 2006. Resistência cruzada da losna-branca (Parthenium hysterophorus) aos herbicidas inibidores da enzima acetolactato sintase. Planta Daninha 24(1):157-162.

12. Geering, A. D. W., and Randles, J. W. 1994. Interactions between a seed-borne strain of cucumber mosaic cucumovirus and its lupin host. Ann. Appl. Biol. 124:301-314.

13. Greber, R. S. 1971. Some characteristics of tobacco streak virus isolates from Queensland. Queensl. J. Agric. Anim. Sci. 28:105-114.

14. Greber, R. S. 1979. Virus diseases of Queensland strawberries and epidemiological effects of the strawberry runner approval scheme. Queensl. J. Agric. Anim. Sci. 36(1):93-103.

15. Greber, R. S., Klose, M. J., Teakle, D. S., and Milne, J. R. 1991. High incidence of tobacco streak virus in tobacco and its transmission by Microcephalothrips abdominalis and pollen from Ageratum houstonianum. Plant Dis. 75:450-452.

16. Haseler, W. H. 1976. Parthenium hysterophorus L. in Australia. PANS 22:515-517.

17. Jayachandra. 1971. Parthenium weed in Mysore State and its control. Curr. Sci. 40:568569.

18. Kaiser, W. J., Wyatt, S. D., and Klein, R. E. 1991. Epidemiology and seed transmission of two tobacco streak virus pathotypes associated with seed increases of legume germ plasm in eastern Washington. Plant Dis. 75:258-264.

19. Kaiser, W. J., Wyatt, S. D., and Pesho, G. R. 1982. Natural hosts and vectors of tobacco streak virus in eastern Washington. Phytopathology 72:1508-1512.

20. Kanchan, S., and Jayachandra. 1980. Pollen allelopathy - A new phenomenon. New Phytol. 84:739-746.

21. Klose, M. J., Sdoodee, R., Teakle, D. S., Milne, J. R., Greber, R. S., and Walter, G. H. 1996. Transmission of three strains of Tobacco streak ilarvirus by different thrips species using virus-infected pollen. J. Phytopathol. 144:281-284.

22. Kumar, S., Tamura, K., and Nei, M. 2004. MEGA3: Integrated software for Molecular Evolutionary Genetics Analysis and sequence alignment. Brief. Bioinform. 5(2):150-163.

23. Maule, A. J., and Wang, D. 1996. Seed transmission of plant viruses: A lesson in biological complexity. Trends Microbiol. 4(4):153-158.

24. Mishra, R. P., Singh, B., and Oommachan, M. 2002. Airborne pollen flora of Jabalur - the central India. Aerobiologia 18:73-81.
25. Navie, S. C., McFadyen, R. E., Panetta, F. D. and Adkins, S. W. 1996. The Biology of Australian Weeds 27. Parthenium hysterophorus L. Plant Prot. Quart. 11(2):76-88.

26. Navie, S. C., Panetta, F. D., McFadyen, R. E., and Adkins, S. W. 1998. Behaviour of buried and surface-sown seeds of Parthenium hysterophorus. Weed Res. 38:335-341.

27. Navie, S. C., Panetta, F. D., McFadyen, R. E., and Adkins, S. W. 2004. Germinable soil seed banks of central Queensland rangelands invaded by the exotic weed Parthenium hysterophorus L. Weed Biol. Manag. 4:154-167.

28. Picman, A. K., and Towers, G. H. N. 1982. Sesquiterpene lactones in various populations of Parthenium hysterophorus. Biochem. Syst. Ecol. 10(2):145-153.

29. Prasada Rao, R. D. V. J., Reddy, A. S Chander Rao, S., Varaprasad, K. S., Thirumala-Devi, K., Nagaraju, Muniyappa, V., and Reddy, D. V. R. 2000. Tobacco streak ilarvirus as causal agent of sunflower necrosis disease in India. J. Oilseeds Res. 17(2):400-401.

30. Prasada Rao, R. D. V. J., Reddy, A. S., Reddy, S. V., Thirumala-devi, K., Chander Rao, S. Manoj Kumar, V., Subramaniam, K., Yellamanda Reddy, T., Nigam, S. N., and Reddy, D. V. R. 2003. The host range of Tobacco streak virus in India and transmission by thrips. Ann. Appl. Biol. 142:365-368.

31. Satheeshkumar, S., and Vittal, B. P. R. 1998. A preliminary survey of airborne pollen in Madras City. Aerobiologia 14:69-73.

32. Sdoodee, R. 1989. Biological and physicochemical properties of Tobacco streak virus. Ph.D. thesis. University of Queensland, Brisbane.

33. Sdoodee, R., and Teakle, D. S. 1987. Transmission of tobacco streak virus by Thrips tabaci: A new method of plant virus transmission. Plant Pathol. 36:377-380.

34. Sdoodee, R., and Teakle, D. S. 1988. Seed and pollen transmission of Tobacco streak virus in tomato (Lycopersicon esculentum cv. Grosse Lisse). Aust. J. Agric. Res. 39:469-474.

35. Shabbir, A., and Bajwa, R. 2006. Distribution of parthenium weed (Parthenium hysterophorus L.), an alien invasive weed species threatening the biodiversity of Islamabad. Weed Biol. Manag. 6:89-95.

36. Sharman, M., Thomas, J. E., and Persley, D. M. 2008. First report of Tobacco streak virus in sunflower (Helianthus annuus), cotton (Gossypium hirsutum), chickpea (Cicer arietinum) and mung bean (Vigna radiata) in Australia. Australas. Plant Dis. Notes 3:2729.

37. Shukla, D. D., and Gough, K. H. 1983. Tobacco streak, broad bean wilt, cucumber mosaic, and alfalfa mosaic viruses associated with ring spot of Ajuga reptans in Australia. Plant Dis. 67:221-224.

38. Sokal, R. R., and Rohlf, F. J. 1995. Biometry. W. H. Freeman and Co., New York.

39. Tamado, T., Schutz, W., and Milberg, P. 2002. Germination ecology of the weed Parthenium hysterophorus in eastern Ethiopia. Ann. Appl. Biol. 140:263-270.

40. Thomas, W. D., and Graham, R. W. 1951. Seed transmission of red node virus in pinto beans. Phytopathology 41:959-962.

41. Towers, G. H. N., Mitchell, J. C., Rodriguez, E., Bennett, F. R., and Subba Rao, P. V. 1977 Biology and chemistry of Parthenium hysterophorus L., a problem weed in India. J. Sci. Industrial Res. 36:672-684. 